\title{
Den etterlatte terapeuten
}

Ved Haldis Hjort

\section{Forfatteren forteller i en personlig stil om erfaringer fra sin mangesidige terapeutiske praksis med pasienters suicid. Hun beskriver egne følelsesmessige reaksjoner og synspunkter på hvordan det faglige miljøet bør takle og bearbeide suicid-hendelser. Hun drøfter også etiske aspekter ved terapeuters skyldopplevelse.}

O gså vi fagpersoner som har opplevd selvmord hos pasienter, er etterlatte. Etterlatte i livet. Etterlatte med sterke følelser, dyrekjøpte erfaringer vi ikke helt vet hvordan vi kan bruke, etterlatte i et arbeid der det kan skje igjen: A t den vi skal hjelpe, gir opp å tro på at hjelpen er sterk nok til at han eller hun orker å være levende. Jeg vil fortelle om mine erfaringer, og gi refleksjoner rundt dem. Jeg var ferdig cand.psychol. i begynnelsen av 1970-årene, og ville bli klinisk psykolog. Jeg tenkte ikke da at det yrket kunne ha noe med døden å gjøre, det var legeyrket som hadde det. Vi hadde ikke lært noe om dette i studiet. A t de vi skulle hjel pe kunne ha det vondt, var én ting, og selvføl gelig visste jeg at selvmord fantes blant personer med psykiske lidelser. $M$ en at jeg som fagperson skulle kunne få det tett, tett inn på meg, hadde jeg ikke fantasi til å kjenne på.

Om døden innenfor rusomsorgen, og om terapeutens angst for skyld

Første gang jeg merket døden i arbeidet mitt, var da jeg begynte på U teseksjonen i 0 slo i 1980. A rbeidet var å oppsøke unge mennesker i 0 slo sentrum som hadde store vanskeligheter: ofte tungt rusmisbruk, bosteds- og arbeidsløshet, helseproblemer, prostitusjon, fattigdom, kriminalitet.

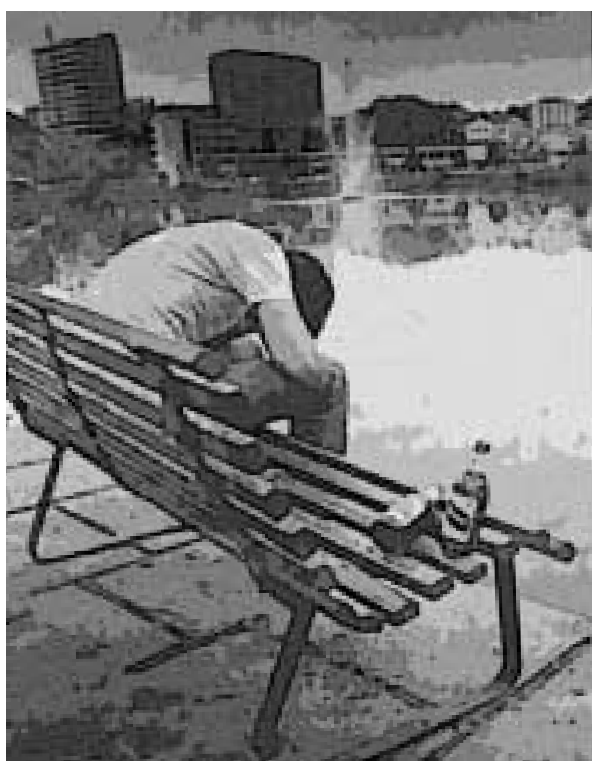

Og ikke minst; de slet med depresjon og angst. M en dette siste "så" vi ikke ordentlig da. J eg mener at et trekk ved omsorgen for unge rusmisbrukere har vært at man først på 1990-tall let begynte å interessere seg ordentlig for hva som er "inni" dem; deres opplevde sorger, tap i livet, vold, overgrep og traumer, manglende kjærlighet i oppveksten og deres store ensomhet i nåtiden. Kort sagt deres psykiske lidelser.

Det var som om vi i åttiårene var så opptatte av de store sosiale problemene hos rusmisbrukende ungdom at vi ikke så suicidaliteten som ligger i det langvarige, tunge stoffmisbruket. Jeg mener nå at det er meningsfylt å forstå dette, liksom anoreksi, som "langtrukkent" selvmordsforsøk. O ver år manifesteres selvhat, følel sen av å ikke ha rett til å leve, i disse handlingene. M en det var jeg ikke ordentlig klar over den gang. Derfor berørte ikke dødsfall i rusmiljøet meg på samme personlige måte som det siden har gjort i psykiatrien. Jeg kunne forskrekkes over at det var vanlig - og gan ske realistisk for disse unge å anta at deres livslengde ble rundt 35 år. De regnet liksom med at man ikke blir eldre, de snakket resignert og rolig om sine venner slik som våre tanter på over åtti år snakker om sine: "..ja, ja, nå har hun også vandret". Jeg tok altså ikke overdosene innover meg som val gte, selvdestruerende handlinger, noe jeg nå tror de i ganske stor grad er. M en er det ikke fortsatt slik at overdosedødsfall sjelden blir vurdert som suicid i offentlig selvmordsstatistikk?

H er kommer vi inn på en reaksjon som vi fagfolk ofte har når pasienter/klienter dør eller har det vondt: "D et er ikke min skyld". D et er som om vi vegrer oss så godt vi kan mot ansvar. Terapeutens selvfølelse er så sårbar, det oppleves tungt å være involvert i et arbeid som handler om liv og død. Derfor er det lettere å "ta" at en rusmisbrukspasient dør enn en som ikke har misbruk. For da kan man trøste seg med en hypotese om at det var et uhell for pasienten; stoffet var for reint, pasienten var truet i misbruksmiljøet eller var ruspåvir- ket da han/hun tok for mye stoff, derfor skjedde det i forvirring - ikke som en reaksjon mot livet, familien eller terapeuten. Det var det uberegnelige rusmidlet eller det asosiale miljøet som hadde skylden. A t pasienten dør for egen hånd forklares med det objektiverende, "nyttige" begrepet overdose. Vi sørger over å ha mistet ham/ henne som vi håpet å hjel pe og er blitt glad i, men slipper skylden. (En liknende skyldfritakende funksjon i vårt fagmiljø kan kanskje vår tids fokusering på genetiske årsaker (mis) brukes til; hvis pasienten var "predestinert" av sine gener til depresjon og selvmord, fritas hjel peren lettere.)

M en hva er riktig og gal skyldfølelse? En moralfilosof i dag som mange er opptatte av, er Levinas (1993). Det sies at et av D ostojevskijs utsagn ful gte ham hele livet: "Enhver er skyldig overfor alt og alle, og jeg mer enn de andre." H vorfor er jeg mer skyldig enn de andre? Fordi det ville øke den allmenne moralske standard hvis enhver orket å se etter bjelken i eget øye før man lette etter splinten i kollegers, pårørendes og andres øyne. Samtidig må man vekte ansvaret riktig, ikke overdrive egen betydning. Jeg må prøve å være profesjonell når en pasient dør, spørre om hva jeg eller teamet kunne gjort annerledes. $M$ en også se de andre kreftene som spilte inn som vi ikke er herre over. Vi er ikke Gud - deus ex machina. D ostojevskijs sentens går ikke mot denne vektingen, men den handler om å orke å se sitt ansvar for "alt og alle", å holde ut i det, uten å bli selvplager.

Wampold (2001) er den forsker som kanskje har meta-analysert flest studier av hva som virker i psykoterapi, og har konkludert med noe som mange av oss klinikere erfarer; at "common factors" der relasjonen mellom terapeut og klient er viktigst, er en mye sterkere faktor (ca. $30 \%$ ) for et positivt resultat enn hvilken terapiteknikk/-metode terapeuten bruker (ca. $15 \%$, se s. 208). M en "extratherapeutic change"; hva som skjer utenfor terapien av tusen ting i klientensliv samt 
klientens egen motivasjon teller likevel enda sterkere (ca. $40 \%$ ). D ette skulle vel gi oss terapeuter en viss ydmykhet; man betyr mye, men slett ikke alt i spørsmålet om en pasient velger livet i stedet for døden. En kollega fortalte om en pasient han hadde hatt i flere år. Pasienten hadde vært mye utsatt mobbing i barndom og ungdom og også for urettferdig behandling på arbeidsplassen, slik at han slet med manglende tillit til andre mennesker. $\mathrm{H}$ an kunne lett få paranoide tanker, men gjennom terapien ble han mindre krenkbar, og det var stor framgang i hans livskvalitet. Så skjedde fatale "ekstraterapeutiske" hendelser; han ble igjen utsatt for usanne beskyldninger om betenkelige transaksjoner, og ble offentlig uthengt. Det rammet hans sårbare psykiske akilleshæl, og han tok umiddel bart sitt eget liv. Terapeuten sørget i mange år over dette og måtte gjøre et stort mentalt sorteringsarbeid om hva han kunne gjort annerledes, og hva som var utenfor hans innflytelse.

I flere studier av terapeuters reaksjoner på pasienters suicid, beskrives følel sen av skyld som en av de hyppigste og sterkeste ( $H$ endin et al. 2000, W olfersdorf et al., 2001, W aern, 2003, Lafayette \& Stern, 2004). M en drøfting av det etiske aspekt ved skyld berøres ikke mye i disse studiene. Dette er viktige temaer innenfor klinisk utdannelse: Terapeutens mentale arbeid med å skjelne mellom en skyldfølelse som har med faglig ansvar å gjøre "jeg kunne gjort noe annerledes", og en skyldfølelse som har med mindre profesjonelle motiver å gjøre, som angst for juridiske etterspill, kollegers kritikk eller pårøren des bebreidelser.

\section{Om å arbeide i akuttpsykiatrien}

I 1985 begynte jeg å arbei de i psykiatrisk akuttavdeling. Jeg tror ikke jeg har lært så mye på noen annen arbeidsplass. Det var et flott personale, og jeg møtte mange pasienter som kom inn med selvmordforsøk, som hadde en nesten kronisk dødslengsel. En av disse var en jeg kaller Elin. $\mathrm{H}$ un var blitt funnet nesten for sent ute i skogen en sommerdag. En ung, vakker, klok jente. Fullstendig upsykotisk, bare gjennomgripende trist. H un sa: "Jeg gir deg sjansen denne høsten til å bli kjent med hvorfor jeg tenker så mye på døden," og fortal te om mange tap i livet. $\mathrm{H}$ un be- skrev sin eksistensielle situasjon på denne måten: "Dere står på en hundrekroneseddel, mens jeg står på en tiøring. $M$ indre er ikke mulig, for femøringen er gått ut av bruk" (nå er femtiøringen minste enhet). En stor kjærlighetssorg hadde vært utløsen de til selvmordsforsøket, hun sa: "Jeg ønsker ikke å leve videre, fordi jeg fikk gi bort alle mine gode følelser til ett menneske. $\mathrm{H}$ an gikk sin vei med dem. Derfor skremmer døden mindre enn ensomheten." H vordan kunnevi ha reddet Elin?

Da vinteren nærmet seg, kom hun på åpen avdeling. Permisjoner er farlige, mange selvmord skjer da! Ved permisjonen til nyttår var det kaldt, hun gikk ut i skogen, og klarte det denne gangen. Jeg skrev i 1993 en historie om en pasient med mange trekk fra Elin i en bok som heter "H istorier om sjeler". I historien sier terapeuten til den døde Elin: "H vis alle som brydde seg om deg kunne holde på deg og rundt deg i to år, og hvis du hver dag gråt og snakket ut sorgen som verker, så kanskje. M en har vi institusjoner hvor man făr slik hjelp i dag?"

Jeg tenker på dette med skyld og ansvar igjen, og vil fortelle noe jeg skammer meg litt over: Fordi Elin var flyttet over til åpen avdeling, var ikke jeg terapeuten hennes lenger. Jeg hadde ikke ansvar for permisjonen, jeg kunne skyve fra meg skyld. H va ville Dostojevskij og Levinas sagt til det?

\section{Om å arbeide i team, og om ansvaret for å være åpen}

Jeg vil si noe mer om å arbeide i psykiatrisk avdeling, i team. Det var mye kjærlighet i akuttavdelingen, og regler for påpassing, fotfølging, utgang, medisinering osv. ble ofte gjennomført med omsorg, ikke bare med kontroll. M en likevel mener jeg at det var ikke nok ressurser til virkelig å matche sel vhatet til de sterkt suicidale. For et team som jobber med disse pasientene, er det lett å bli splittet. Jeg husker en diskusjon vi hadde en gang om en ung mannlig pasient som lignet på Elin ved at han syntes å være kronisk suicidal.

$\mathrm{H}$ an hadde prøvd å henge seg $\mathrm{i}$ avdelingen blant annet. En utsl itt sykepleier sa: "For noen er det ikke liv laga". Jeg reagerte moralsk forarget da: Så defaitistisk kan man ikke være, til nød kan det sies, eller tenkes, om gamle mennesker som man har jobbet lenge med. Siden har jeg tenkt at det var lettere for meg å ha energi og være forarget enn sykepleieren som hadde funnet pasienten hengende og som miljøarbeider opplevd ham igjen og igjen ved nye innleggel ser. $M$ en dette viser splittel sesfaren i et slitent team. E kstreme situasjoner krever ekstreme mottiltak: Teamomsorg er livsnødvendig - eller i hvert fall nødvendig for at ikke sykefraværene skal bli høye. Et annet eksempel fortalte fagpersonen "A nna" fra den gang hun var en ung, uerfaren nattevakt: $H$ un opplevde suicid av en pasient på natten.

0 verlegens utsagn på morgenmøtet etter var fatalt: "Bryr dere dere ikke om pasienten?" Den formelle leder og autoritet projiserte skyld. "A nna" torde først ikke komme på miljøterapeutmøtet etterpå hun følte hun hadde all skyld. "A nna" kaller det overlegen gjorde, for "stygt", det ble traumatisk og hun har mange år etterpå ikke helt klart å tilgi ham.

I 2006 gjorde vi en kvalitativ undersøkelse av akuttavdelinger, der vi intervjuet ulike faggrupper ( $H$ jort og Ruud, 2006). $\mathrm{N}$ oen av de sterkeste budskapene kom fra miljøarbeidere som hadde mange års erfaring i akuttarbeid. $\mathrm{H}$ er er et utsagn fra en av dem: "Jeg har opplevd en del situasjoner som har vært veldig, veldig belastende, fordi jeg i utgangspunktet var uenig i behandlingen. For eksempel en pasient som gav meg så dårlig følelse, og mot alles vilje gikk jeg inn på hennes rom, jeg bare måtte gjøre det. Jeg fant henne bevisstløs og reddet henne da. H vilke yrkesgrupper eller personer făr autoritet? D et sies at det har vært mange unge uerfarne assistentl eger, der erfarne sykepleiere sa at 'dette gjør du bare ikke'. $M$ an bærer bekymringen i seg, man følger opp pasienter, og vet fra vakt til vakt hva de står i. Det er klart at når du da går av vakt og rapporterer videre at avløserne må passe på, for det er lite som skal til før... da gjør det noe med deg. O g hver gang det skjer igjen, så bærer du en del med deg. Det kan være mennesker du har kjent kanskje i flere år, det har vært mange innleggelser. Du har kjent barna deres, ektefelle, foreldre. Det er klart at det gjør jo noe med deg, men du kan ikke gå og tenke sånn i hverdagen...".

Selvmord er en ekstrem handling, et uttrykk for den ytterste ensomhet. 
Personen har gitt opp å tro på en mulighet for at samvær med andre skal lege sår, gi varme, gi tro på at "livet er no det likaste lell", som Per Sivle skrev. O g Pär Lagerkvist: "Den ensamma er svagast. Ej för han ensam er, men för att han förnekar det han inom sig bär. ...Den väg du går allena för bort ifrån dig själv."

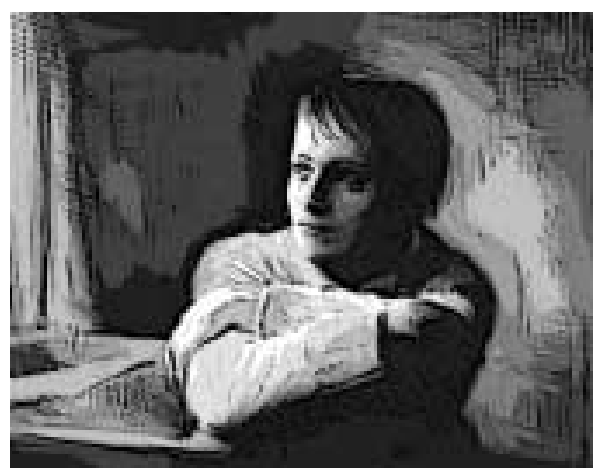

O g vi forstår av utsagnet til miljøterapeuten ovenfor at når dette ekstreme uttrykket for ensomhet skjer, må miljøet takle det med samme grad av ekstrem motsats: stå sammen, støtte hverandre, trøste hverandre, bære ansvaret sammen. Ellers mister fagmiljøet de beste og mest erfarne målet er jo å kunne arbeide med slike pasienter lenge. Særlig må den som har den formelle makt i behandlingshierarkiet være villig til å ta på seg ansvar - det er en av grunnene til at han/hun får den høye Iønnen. A lle må møte til debriefing og sorgarbeid (hvem tror du det er fare for at ikke kommer?). Vi må snakke sammen om dette, det må vi, eventuelt med en teamterapeut utenfra. $\mathrm{H}$ vis ikke fagmiljøet får bearbei det sine reaksjoner som oppstår etter et selvmord, kan det føre til traumer, angst for å møte denne typen pasienter siden, tretthet, utslitthet og sykemeldinger. Den konstruktive, håpefulle holdning er å orke å være åpen, undersøke hendelsen i detalj, spørre "hva kan vi lære av dette". Teamet må si "våre" feil (se Peter H jort, 2004), men også finne ut hva man gjorde som var bra, for ros smelter. $\mathrm{Vi}$ skal være forsiktige med ordet problem, men bruke utfordring. Terapeutene skal overleve. Den største utfordring terapeuter kan ha, er å møte pasienter som lever nær døden. Personalets følel ser må tas på alvor for at vi skal kunne gå videre og hjelpe neste pasient.

I flere studier påpekes det at koll egers eller arbeidsmiljøets støtte er en uhyre viktig faktor for om terapeuten får bearbeidet belastningen ved en pasients suicid og kan gå videre, eller bærer med seg opplevelsen av å være sviktet $i$ årevis (Hendin et al., 2000, W aern, 2003, Lafayette \& Stern, 2004).

\section{Om å arbeide i privatpraksis, og om kollegers støtte}

En annen pasient jeg møtte i akuttavdelingen var Karen. H un var innbrakt etter et alvorlig sel vmordsforsøk, hadde gjort flere før, og var psykosetruet. Jeg har aldri møtt noen som har hatt så pågående, aggressive, indre stemmer. $0 \mathrm{~m}$ natten kom de i mareritt, det handlet om mord, evig fortapel se i helvete, opplevelse av synd for hemmelige seksuelle følel ser.

Karen er den som har lært meg mest om suicidalitet, med sine tanker om skyld og ansvar. M en det har kostet - at hun døde vil alltid sitte der som en "torn i kjødet". Jeg tenker ofte på henne, ser henne for mitt indre blikk; øynene hennes var så blå, så blå. $\mathrm{H}$ un hadde et så fint vesen; ordet from kommer ofte opp når jeg tenker på henne. Hun beveget seg mellom akuttavdeling, langtidsavdeling og somatisk sykehus etter suicidforsøkene (i dag hadde så lange opphold i akuttavdeling selvfølgelig ikke vært mulig). Fra ca. 1989 klarte hun å holde seg utenfor psykiatrisk sykehus. H un var fanatisk imot medisinering og innleggelse. Så kom hun rundt 1990 og spurte meg om jeg ville ta henne i poliklinisk behandling, og jeg sa ja (jeg hadde sluttet i akuttavdelingen i 1988).

Jeg følte at jeg ikke strakk til, at det var for vanskelig å gi Karen poliklinisk behandling, eller at jeg skulle hatt et mye sterkere behandlingsnettverk rundt oss. $M$ an var ikke kommet så langt den gang med an svarsgrupper, støttefunksjoner, "individuell plan" - strukturer innen psykisk helsevern som er mer utviklet i dag. Jeg kunne til tider stå i fare for å bli en "pårørende", for hun var så ensom, og det var mye hun følte hun ikke kunne fortelle familien. Jeg plagde meg med tanker om jeg var uprofesjonell når jeg ble den som ga emosjonell næring. $M$ an kan og skal ikke la være å engasjere seg og føle for personen. M en terapeuten kan vel ikke bli pasientens begrunnelse for å leve, ikke i lengden.

Jeg vil si det slik at det var traumatisk for meg den dagen familien ringte og sa hun var funnet død (jeg skrev et "brev" til den døde Karen i Suicidologi 1998, nr. 2). Jeg besøkte familien neste dag og fikk hennes siste brev til meg. Jeg var redd for å lese det - det var dette med skyldfølelse igjen - jeg var redd hun ville bebreide meg. $0 \mathrm{~g}$ det var vanskelig overfor pårøren de, man har jo også taushetsplikt overfor den døde. Jeg vil alltid forsvare hennes ettermæle; hvis det er misforhold mellom hva hun har fortalt meg som jeg tror på, og hva som kan bli sagt om henne.

M en jeg opplevde hvor viktig det er med kollegers støtte for at man som behandler skal få bearbeidet sine traumer og våge å fortsette å arbeide med suicidale mennesker. Like etter Karens død snakket jeg med noen av de på klinikken som hadde kjent henne. I en slik situasjon er man så sårbar, og tilsvarende mottakelig for trøst. Jeg skal aldri glemme hva A strid $\mathrm{N} ø$ kleby $\mathrm{H}$ eiberg sa, det var som en utrolig lindrende bandasje: "Du må huske på at også psykiatrien har sin mortalitet". $0 \mathrm{~g}:$ "K anskje fikk du henne til å leve lenger". J eg skjønte at på den måten kan det sammenlignes med fysisk sykdom. Kirurger må også gi tapt, bære angsten for at opererte pasienter ikke overlever - det sies at gamle overlegekirurg Efskind sa: "Jeg liker ikke å møte tomme korridorsenger når jeg kommer på jobb om morgenen." M en vi i psykisk helsearbeid har det på noen måter verre enn de i somatikken. Vi kan ha kjent pasienten mye lenger enn en kirurg, vi har en bredde av kjennskap til personen, som vi blir glad i. N oe som er lettere for oss fordi angsten for skyl dfølelse gjør oss egoistiske, er at skyldfordelingen er enklere i somatikken; at fagpersonen skjærer feil med døden til følge, er lettere å fastslå enn hvis man sier noe feil.

Karen bærer jeg med meg i min hukommelse - som en erfaringsskatt og som et traume. N år jeg i poliklinisk virksomhet får en ny pasient der jeg tror jeg "lukter" suicidalitet, stikker tornen i kjødet, en klokke ringer. Jeg fikk for eksempel en pasient, $M$ artin, hvis bror hadde vært innlagt i klinikken der jeg hadde kontor, og som hadde tatt livet av seg på permisjon. $M$ artin hadde motforestillinger til à gå hos meg rett og slett fordi jeg befant 
meg i samme huset, og han hadde tvangstanker om at han måtte gå samme vei som broren. D a veltet følelser opp i meg; irritasjon overfor uforsiktige permisjonsgivere, angst for gjentakel sestvangen hos $M$ artin, gamle spøkelser. $N$ år slikt skjer, må jeg gå en runde med meg selv. Jeg vil ikke lenger jobbe så ubeskyttet som med Karen. M en samtidig må disse pasientene få et tilbud. $0 \mathrm{~g}$ hvorfor ikke jeg som alle andre noenlunde erfarne fagfolk? Jeg må fortelle meg selv at jeg sannsynligvis vet mer en $n$ en del andre, og mer enn den gang med Karen, og at man aldri vet nok. Terapeuten må handle likevel, våge å ta ansvar og akseptere sin ufullkommenhet. Jeg kan ikke vente til jeg er pensjonert med å tro at jeg er klok nok. Jeg må gå en runde med min forfengelighet - angsten for å få omdømmet "hun hvis pasi enter tar livet av seg". M å fortelle meg selv at det kan handle om et statistisk spørsmål, nemlig en terapeuts utvalg av pasienter, heller enn terapeutens dyktighet. A t omdømmet kan redefineres: Vedkommende terapeut har mange tunge pasienter.

Om at terapeuten må Iære selvbeskyttelse, og likevel ha mot

Her er eksemplet Berit: Etter en stund i behandling i min privatpraksis begynte Berit med en masse selvskading. Ikke livstruende, men skremmende. Jeg kom inn i sirkelen med å gå utover vanlig arbeidstid, gi ekstra timer, hun kunne ringe meg om kvelden. $\mathrm{N}$ år hun gikk fra en time, kunne jeg få plutselige engstelige tanker: "Kommer hun til å kaste seg foran en bil eller trikken slik hun antydet?" Det ble en del korte innleggelser og masse krisearbeid. Jeg ble sliten. En dag sa jeg: "Jeg klarer ikke arbeide godt når jeg blir redd og det er krisemaksimering. Kan du gi terapien ett år, hvor vi arbeider i fred og ro, og du gir meg løfte om ikke å gjøre selvmordsforsøk?" H un ville ikke svare da, men på slutten av timen, idet hun reiste seg, sa hun: "OK, da". D et var et vendepunkt. Etter noen uker sonderte jeg hva hun følte for dette løftet. H un sa forarget: "Tror du ikke jeg vet hva et løfte er? Tror du jeg gir det uten å stå for det?" Så roet jeg meg. $M$ an vil kanskje si at en person skal være ganske "frisk" for å gi et Iøfte. M en jeg tror at for enhver person har det å eie en mulighet for å innestå for noe, med verdighet å gjøre. Det gir identitet. En annen ting er at det kan være fint å snakke om dette løftet av og til - at begge bekrefter sin arbeidsavtale.

A v Berit har jeg lært at når man kan be om et løfte, har faktisk mindre å gjøre med hvor sterk pasientens psykiske lidel se er, og mer med hvor fort man kan skape tillit. $0 \mathrm{~g}$ siden jeg er blitt flinkere, er jeg ikke redd lenger for å spørre en pasient om han/hun har selvmordstanker. 0 g jeg ber, hvis det er relevant, nå oftere tidlig i terapiarbeidet om en arbeidsavtale, om å legge suicidaliteten på hylla for en tid - ikke nødvendigvis tankene, men planer.

En side ved å lære selvbeskyttelse er å øve seg på selverkjennelse. I løpet av min lange tid som terapeut har jeg opplevd at det går an å utvikle seg fra å være opptatt av det vi lærer om regler og teorier for terapi, til å våge å stole mer på intuisjon, tenke mer konkret på hva som passer for akkurat denne pasienten i denne timen, på dette sted, i denne situasjon. Det betyr ikke at det jeg har lært av regler og teorier forkastes, men at jeg kan våge å overskride dem (H jort, 2003, s. 362-363). Rønnestad og Skovholt (2001), som har forsket på terapeutkarrierer, utbrenthet og faglig utvikling gjennom mange år, siterte en respektert kvinnelig terapeut som fortal te slik om sin egen praksis:

"W e have a very narrow path that you had to follow, and you watch your step so you don't fall off the edge. .. but now, at age 78, it is like walking in a wide world that has forests, deserts, rivers, oceans and mountains, and it is like you go into it with your hiking boots and there is lots of grass, and you can sort of walk around without fear, and everything is more comfortable..."

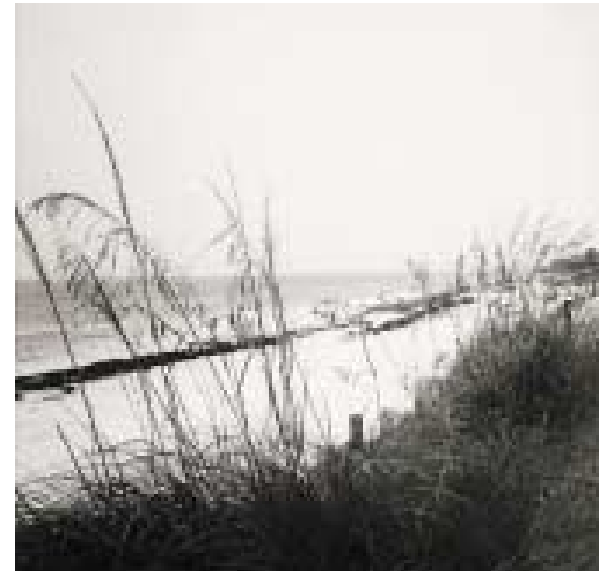

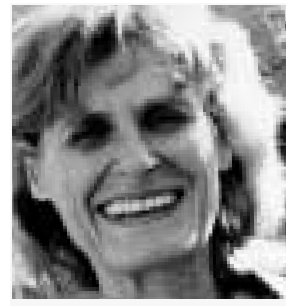

$\mathbf{H}$ aldis $\mathbf{H}$ jort er spesialist i klinisk psykologi og dr.psychol. $\mathrm{H}$ un har arbeidet på de fleste områder innen psykisk helsevern og rusomsorg $\mathrm{i}$ O slo kommune. H un har nå deltids privatpraksis med driftstilskudd og $50 \%$ stilling som seniorforsker ved Sintef, A vdeling for psykisk helse.

\section{Referanser:}

Brudal, Lisbeth F. (1998). D ødsbevissthet. 0 m å velge livet eller døden. 0 slo: U niversitetsforlaget.

$H$ endin, H ., Lipschitz, A ., M altsberger, J.T., Pollinger, A.H.\& W ynecoop, S. (2000).

Therapist's reactions to patient's suicide.

A merican Journal of Psychiatry 157, 2022-2027.

H jort, H . (1993). H istorier om sjeler. O slo: Pax. H jort, H. (1998). Til en pasient, da budskapet kom om at hun hadde tatt livet av seg. Suicidologi, $3(2): 20$.

H jort, H. (2003). I deer i norsk psykoterapi. $U$ tviklingslinjer og brytninger 1970-2000. 0 slo: U nipub.

H jort, H . (2004) H vem gir behandleren sitt hjerte til; fagfellene/kollegene/terapiskolene eller pasientene/klientene/brukerne? Impuls, 58, 2.

H jort, H. \& Ruud, T. (2006). En kvalitativ studie av akuttavdelinger i psykisk helsevern. Sintefrapport ST F78 A 06012.

H jort, P. F. (2004). U heldige hendelser i helsetjenesten. Forslag til program for forebygging og håndtering. Rapport til Sosial- og helsedirektoratet.

Lafayette, M.J. \& Stern, T.A . (2004). T he impact of a patient's suicide on psychiatric trainees: A case study and review of the literature. $H$ arvard Review Psychiatry, 12, 49-55.

Levinas, Emmanuel (1993). D en annens humanisme. 0 slo: A schehoug.

Rønnestad, M. H.\& Skovholt, T. M.(2001). Learning arenas for professional development: Retrospective accounts of senior psychotherapists. Professional Psychology: Research and Practice, 32, 181-187.

W aern, M . (2003). N är patienten väljer döden. Läkartidningen 24, 2140-2143.

W ampold, B. E. (2001). T he great psychotherapy debate. M odels, methods and findings. $N$ ew Jersey: Lawrence Erlbaum A ssociates.

W olfersdorf, M ., Vogel, R., Kornacher, J., R upprecht, U., Franke, C. \& W urst, F. (2001). N ach dem Suizid eines Patienten - Erfahrungen mit A ngehörigen von Suizidenten in der psychiatrischen Klinik. Psychiatrische Praxis 28, 341-344. 